\title{
THE REMAINS OF THE LETTERS. THREE READING PARADIGMS IN THE GHETTOS
}

\author{
JOANNA ROSZAK ${ }^{1}$ \\ (Polska Akademia Nauk, Warszawa)
}

Keywords: Holocaust, ghetto, afterimage

Słowa kluczowe: Holokaust, getto, powidok

\begin{abstract}
Joanna Roszak, THE REMAINS OF THE LETTERS. THREE READING PARADIGMS IN THE GHETTOS. "PORÓWNANIA" 2 (21), 2017, P. 225-242. ISSN 1733-165X. In June 1942 Emanuel Ringelblum asked: "What kind of books do people read? This topic has always been interesting for each Jew and after the war it also became interesting to the world". This topic hasn't received a comprehensive study yet. The author of the paper The Remains of the Letters. Three Reading Paradigms in the Ghettos examined this aspect of history of the ghettos. The literature allows us to shed light on the topic of the life and deaths of their inhabitants. But, taking up this topic enables us also to activate new ways of interpreting the books. The volumes they spent time on in the ghetto allow to capture the way the residents of the ghettos built or broke the bond with the reality, how they taught their own children to read or found solace in someone else's pain. The author considers, however, whether the studies of ordinary life in extraordinary times of the Holocaust can be considered micro-historical.
\end{abstract}

Abstrakt: Joanna Roszak, RESZTKI LITER. TRZY PARADYGMATY LEKTUROWE W GETTACH. „PORÓWNANIA” 2 (21), 2017, S. 225-242. ISSN 1733-165X. W czerwcu 1942 roku Emanuel Ringelblum zauważył, że temat żydowskich lektur w gettach będzie interesował świat. Tak zakreślony problem badawczy nie doczekał się dotąd kompletnego studium. Autorka artykułu Resztki liter. Trzy paradygmaty lekturowe w gettach poddała refleksji ten aspekt historii gett. Literatura w nich obecna pozwala na rzucenie światła na temat życia i umierania ich mieszkańców. Ale podjęcie tego tematu pozwala także uaktywnić nowe tropy w lekturach książek, po które sięgali Żydzi. Tomy, z którymi spędzali czas, pozwalają uchwycić, jak mieszkańcy gett budowali więź z rzeczywistością, jak uczyli dzieci czytać lub znajdowali konsolidację w opisanym cierpieniu. Autorka stawia także pytanie, czy studia nad „zwyczajnym” życiem podczas Holokaustu można uznać za mikrohistoryczne.

1 E-mail: joannamroszak@gmail.com 


\section{Introduction}

Antonina Żabińska, who was the wife of the Warsaw Zoo director, created an ark for people who were fugitives from the ghetto. In the volume Ludzie i zwierzęta she wrote how she was trying to dissuade her son from thinking about the war. Images passing through stories proposed to him were meant to drive away the terrifying reality. Thus, one of the paradigms is built, present also in the ghetto, because adults attributed a role to books - to occupy children in these long hours dragging on like weeks, often in secret, where silence was required:

So as to entertain him, I dropped my occupation and in the child's room, having settled the little kid next to me, I started to read still irreplaceable Robinson Crusoe. But he was squirming, strangely restless as if he had a premonition of something, and he was listening absent-mindedly how Robinson was liberating Friday.

Suddenly winter silence was broken by the rumble of rifle shots. [...]

- Mum, what is it? Who is shooting? Mum!

He was pulling my hand, tugging, and I was looking into the opened book blankly; letters skipped before my eyes, I couldn't utter a word. I did not know at that time how many people would suffer that fate which our animals had suffered ${ }^{2}$.

In another part of the notes by Żabińska, the terror encourages people to read and to prepare descriptions containing everything that the boy could not express himself adequately. This world learned earlier, built from words, overlaps the real world as an afterimage (I make this a keyword in the article). An optical afterimage consists in seeing for a moment in a complementary colour a blurred shape of an image of something which was observed by a viewer for some time and later the viewer averted his or her eyes from it. In the concept proposed here, a literary after-sensation becomes not an optical but receptive category. I am especially interested in afterimage texts, more prose than poetic; they were supposed to alleviate the spiritual hunger.

Jews living in ghettos often looked for such books that would allow them to feel like the protagonists of plots. They instinctively chose books which they read because of their own experiences, sometimes identifying themselves by the similarity, there-

2 „Aby go czymś zabawić, rzuciłam swoje zajęcia i w dziecinnym pokoju, usadowiwszy malca przy sobie, zaczęłam mu czytać wciąż jeszcze niezastąpionego Robinsona Cruzoe. Kręcił się jednak, był dziwnie niespokojny, jak gdyby coś przeczuwał, i w roztargnieniu słuchał, jak Robinson uwalnia Piętaszka.

Nagle ciszę zimową przerwał huk karabinowych wystrzałów. [...]

- Mamo, co to znaczy? Kto strzela? Mamo!

Szarpał mnie za rękę, tarmosił, a ja patrzyłam tępo w otwartą książkę; litery skakały mi przed oczyma, nie mogłam wykrztusić słowa. Wtedy jeszcze nie wiedziałam, ilu ludzi czeka ten sam los, który spotkał nasze zwierzęta" (Żabińska 44-45). If not stated otherwise, all the translations in square brackets are done by Joanna Modzelewska-Jankowiak. 
fore they preferred books that showed historical determinism. They read e.g. novels by Charles Dickens set in a myth, War and Peace by Leo Tolstoy, notes by Marcus Aurelius, Diderot, the novel series by Marcel Proust (Janusz Korczak), volumes by Miguel Cervantes, Rudyard Kipling, poetry by Juliusz Słowacki or Rabindranath Tagore.

Therefore, I introduce the second paradigm, asking what books the residents of ghettos (I limit the reflection mainly to the Warsaw Ghetto, only sometimes I find analogies with other cities) could find as reflecting their unprecedented situation, adequately or at least in an approximate manner. These patterns will hold my interest in a special way.

Another fragment by Antonina Żabińska, from outside the ghetto, allows us to see the space of the ghettos and to move the imagination, which often moves knowledge as well. Żabińska wrote about the return to the zoo as follows: "Our feet got bogged down in pieces of papers and pages from torn books. We crouched down, with our fingers digging in this debris like in the sand"3. This passage of torn pages refers our associations to the poem Campo di Fiori by Czesław Miłosz: "At times wind from the burning / Would drift dark kites along / And riders on the carousel / caught petals in midair" [trans. Louis Iribarne, David Brooks] (Miłosz 29) ${ }^{4}$. The interlocutor of Mikołaj Grynberg, Władek Kornblum, another observer of the Warsaw Ghetto, an escapee from it, remembered vividly that these were mainly black kites with letters of the Hebrew alphabet: "I was ten and one-half years old already, for it was in April 1943. I remember it best when the shreds of burnt books came flying and how they were falling down, I saw the remains of Hebrew letters on them"

The topic "what was read in the ghetto" enables to do more than simply enumerate the books from which those black kites were sent, or rather they sent themselves, it allows us to do more than to prepare an inventory of the books which were read. The books with which the Jews spent time allow you to capture, how residents of ghettos built the bond with reality or broke it, how they found timid hope, taught their own children to read in a hushed voice, or found solace in someone else's pain. In the article I will tackle the actualising methods of reading. Reading in criminal times can be likened to the introduction of a spiritual element, to the order of existence or to seeking an opportunity to slip to the end together with a book when the synchronisation identification is impossible.

The subject makes us follow the intentionality of selected books. It is also worth examining where the memory of readers leads after the war, which storylines man-

3 „Nogi grzęzły w miękkiej warstwie papierów i kartek z podartych książek. Przykucnęliśmy, grzebiąc palcami w tych szczątkach, jak w piasku" (Żabińska 251).

4 "Czasem wiatr z domów płonących / Przynosił czarne latawce, / Łapali skrawki w powietrzu / Jadący na karuzeli" (Miłosz 28).

5 „Miałem już dziesięć i pół roku, bo to było w kwietniu czterdziestego trzeciego. Najlepiej to pamiętam, jak przylatywały strzępy spalonych książek i jak spadały, to ja na nich widziałem resztki hebrajskich liter" (Kornblum 155-156). 
aged to successfully capture anxiety and propose adequate definitions of humanity or a lack of it. The practice of choosing books marked with fictional heroic suffering built a sense of community.

\section{To find oneself in a plot}

Perhaps the residents of ghettos read for one more reason - in order to find at least muddy assurance that they would make their presence felt, but also to feel that someone would write their history (I am paraphrasing the title of the book by Samuel Kassow), as e.g. the history of Musa Dagh had been written previously. The effectiveness of the thesis will induce me to discuss two novels.

Emanuel Ringelblum, the chronicler of the Warsaw Ghetto, in January 1942 wrote about the trading of books:

There are no Jewish bookshops. They have been closed and books have been taken away. [...] The main centre is Leszno street where the best works by currently fashionable writers are selling. The prohibited goods are also here, such as works by Feuchtwanger, Zweig, Kautsky, Lenin, Marx, Werfel, and others $[\ldots]^{6}$

In June 1942 he asked:

What people read? This topic is interesting for each Jew and after the war it will be interesting for the world. The world will ask: What did people from Musa-Dagh think, [people] from the Warsaw Ghetto who understood that they would not avoid death [...]. They read diaries by Lloyd George, novels of world literature about the previous world war, etc., they enjoy reading these pages where the year 1918 is described, the defeat of Germany ${ }^{7}$.

Franz Werfel appears twice in these paragraphs. Firstly, his name was mentioned, secondly, he is represented by the title of the novel The Forty Days of Musa Dagh ${ }^{8}$. The Austrian writer notes about its hero, Gabriel, the defender of the Armenians: [Af-

6 „Nie ma żydowskich księgarń. Zamknięto je, a książki zabrano. [...] Głównym ośrodkiem jest ul. Leszno, gdzie sprzedaje się w koszach najlepsze dzieła modnych ostatnio pisarzy. Nie brak tu również zakazanego towaru, jak dzieła Feuchtwangera, Zweiga, Kautsky'ego, Lenina, Marksa, Werfla i innych [...]" (Ringelblum 353).

7 „Co czyta ludność? Temat ten ciekawi każdego Żyda, a po wojnie będzie interesował świat. Świat zapyta: Co myśleli ludzie z Musa-Dah, [ludzie] z getta warszawskiego, którzy rozumieli, że nie ominie ich śmierć [...]. Czytają pamiętniki Lloyda George'a, powieści światowej literatury o poprzedniej wojnie światowej itp., czytają z upodobaniem te strony, na których opisany jest rok 1918, klęska Niemiec (czerwiec 1942)" (Ringelblum 399-400).

8 Writing about The Forty Days of Musa Dagh I'm quoting a few paragraphs from my previous article in Polish (Roszak 2015). 
ter an attempt to read the first five lines of the novel [...] he closed the book. It seemed to him that he would never be able to deal with any book] "Po próbie przeczytania pierwszych pięciu wierszy powieści [...] zamknął książkę. Wydawało mu się, że w tym życiu nigdy już chyba nie potrafi zająć się jakąś książką" (Werfel 428). Here the third paradigm appears: inability to exploit books and yearning for them at the same time.

In the title of the novel, Werfel included the name of the place where five thousand inhabitants of Armenian villages put up resistance to the Turks for 53 days in September and October 1915. Louis Kronenberger described the work as "a noble story that has to wake up the emotions of all human beings" (Kronenberger). It is significant both as a testimony of the Armenian Genocide and as a document of their lives, and therefore the residents of ghettos assigned a particular importance to it.

The old adage says: „It is impossible to be Armenian”. Similar sentences are written about the extremes of the Jewish fate. The historian Yair Auron rightly stated that the reader of the novel by Franz Werfel would find it difficult to believe that the book was written before the Holocaust. The importance of the novel increased during the Second World War. Musa Dagh was often compared to the resistance in the Jewish ghettos. Marcel Reich-Ranicki recalled that the novel by Werfel was the most widely-read novel in the Warsaw Ghetto. The situation of the ghetto in Białystok was often compared to Musa Dagh. In 1943 Mordechai Tenenbaum, sent to organise an uprising there, used the novel at meetings as a model of resistance. He believed that the only thing the Białystok Jews could do was to organise Musa Dagh. Among the defenders of the Białystok ghetto, who compared their situation to the situation of the Armenians, the copies of the novel „were passed from hand to hand" as Haika Grossman recollected (Grossman 125, quoted from: Auron 157). The statistical records conducted by Herman Kruk in the library of the Vilna Ghetto show that the book was the most popular also among local readers. The Jews must have experienced deeply the passage: „they were convinced that Musa Dagh is threatened with the extermination from all four directions of the world" .

Auron noticed an impact of the novel by Yitzhak "Antek" Zuckerman: "When he wanted to enlighten us he said that it was impossible to understand the Warsaw ghetto uprising without reading Franz Werfel's The Forty Days of Musa Dagh. [...] This Jew understood the Armenian soul better than he understood the Jewish soul" (Auron 305). Zuckerman wrote in the note about Werfel that his book on the massacre of the Armenians had been read in the ghetto especially by the young. Auron found confirmation for these words in the memoirs by Inka Wajsbort. In 1941, when she was less than 16 and belonged to Hashomer Hatzair in Sosnowiec in Lower Silesia, she immersed in Werfel's novel for four days: "If I raised my eyes from the book it was only to let out a cry" (Wajsbort 33-34, quoted from: Auron 158). She stressed: "At the time, I was not yet comparing it with the Holocaust, that sum-

9 „byli przeświadczeni, że zagłada zagraża Musa Dah ze wszystkich czterech stron świata” (Werfel 293). 
mer 1941; I did not yet feel the approach of a new Musa Dagh. That came later" (Wajsbort 33-34). David Shavit determined that the novel by Werfel in the libraries of the European ghettoes under the Nazi occupation was the most frequently read book, apart from War and Peace by Leo Tolstoy. In turn, Arkadius Kahan mentioned that it was borrowed only for three days because there was a queue of people willing to read it (Wajsbort 307).

Book Two of the novel is entitled The Struggle of the Weak and tells about starvation like Polish ghetto testimonies known to us. The set of these afterimage post interpretations, meshing together and synoptic, could be developed further. Besides, it is characteristic that the novel tells about a historical event, but it can be read as a parabolic testimony of each genocide. The parabolic path of reading is reinforced by the fact that there were six, not seven villages at Mount Sinai, and the Armenian resistance at Musa Dagh lasted for 53 days, not 40. The title number has got, of course, biblical connotations and it appears approximately two hundred times on the pages of the holy book: the flood lasted for forty days, Moses spent forty days on Mount Sinai waiting for the words of the covenant which he wrote on the tablets, the tribes of Israel walked across the desert for forty days, David was awaited for forty days, Jesus was in the desert forty days.

\section{I am Jean Valjean}

Even if the popularity of the novel that I will address on the whole gave way to War and Peace by Tolstoy, it is this very novel that can be interpreted today in the category of afterimage. The book Les Misérables by Victor Hugo, who previously wrote about the uprising of slaves and claimed the liberation of John Brown, allows you to associate it with the space of the ghetto in a multifaceted manner. Thus, the musical by Claude-Michel Schönberg can be understood at an even higher level of adoption (the central song-hymn acquires a new dimension, it is sung twice in the musical by those who no longer wish to be slaves: "Do you hear the people sing? / Singing a song of angry men?"). Here is a significant chain of enumeration: Jean Valjean is a man-number, prisoner 24601, a runaway galley slave who landed in prison for stealing a loaf of bread for dying children; a character of Fantine is related to an authentic woman, seen by Hugo, the writer-conscience of humankind (Serkowska 9), in 1841 when a bourgeois threw snow at a prostitute and she sold him her hair and a tooth; Cosette's daughter abandoned to innkeepers near Paris; Valjean disguising his true identity, his moving along sewers and anagnorisis leading to destruction. All these elements may associate the space of the ghetto and, with the influence of contemporary books, they may organise the reader's imagination in such a manner that he or she would not see the streets of Paris of 1832, but Warsaw of 1943. This is confirmed by the statement of a user of one of foreign discussion fo- 
rums: in Les Misérables he sees the Warsaw Ghetto and hears sobbing of the cinema. The adaptation to the new situation has got an interesting potential ${ }^{10}$.

The shreds of Hugo's novel, in fact very popular among Yiddish readers, were also flying with their remains of letters like black kites over the Warsaw Ghetto. Ruth $\mathrm{R}$. Wisse, emphasising the relationship between the Yiddish language and the fate of European Jews, noted, mentioning the author of notes of the Vilna Ghetto made in the years 1941-1943, a boy born in 1927 and shot in Ponary during the liquidation of the ghetto on 1 October 1943: "In the Vilna ghetto, Yitskhok Rudashevski and his school chums drew his models of resistance from Der giber in keytn [Hero in Chains], a shortened translation of Victor Hugo's Les Miserables" (Hugo 1925; Wisse 198).

Let me add that the Polish translation of the novel appeared shortly before the original was launched onto the market. Felicjan Faleński and Edward Sulicki translated it on the basis of a copy of the manuscript purchased from the publisher. As early as in the 19th century subsequent translations were prepared, by Wincenta Limanowska and Klemens Podwysocki ${ }^{11}$.

Therefore I will quote, and leave no comment, fragments that for the residents of the ghettos could be a testimony of resistance or build community of fate, and it allows the contemporary reader to experience the afterimage reception:

[...] cold and piercing air penetrated the room abruptly, he closed it again immediately. He scrutinized the garden with that attentive gaze which studies rather than looks. The garden was enclosed by a tolerably low white wall, easy to climb. Far away, at the extremity, he perceived tops of trees, spaced at regular intervals, which indicated that the wall separated the garden from an avenue or lane planted with trees (Hugo, s.d, 174).

[...] during his studies on the penal question and damnation by law, that the author of this book has come across the theft of a loaf of bread as the point of departure for the disaster of a destiny. Claude Gaux had stolen a loaf; Jean Valjean had stolen a loaf. English statistics prove the fact that four thefts out of five in London have hunger for their immediate cause.

Jean Valjean had entered the galleys sobbing and shuddering; he emerged impassive. He had entered in despair; he emerged gloomy.

What had taken place in that soul? (Hugo, s.d, 153)

10 http://mdn.chanvrerie.net/modernizing-les-mis_o_t_t_70414.html "I'd almost rather see a heavily-adapted Les Mis that tried to tackle a subject like the Paris banlieue, than one that was set during the Warsaw Ghetto Uprising where nobody's going to have their ideas of villains and victims challenged. I mean, I'd totally go see Warsaw Ghetto Les Mis. And it would probably hit all my emotional buttons and I'd leave the theater sobbing. But Les Mis adapted to fit a current, thorny, controversial situation has the potential to be so much more interesting".

11 In the 20th century the book Les Misérables was translated into Polish by Krystyna Byczewska and its fragments by Ludmiła Duninowska. 
The great topic of all the texts related to ghettos is hunger, and it is also the royal topic of Les Miserables. In accordance with the hierarchy of human needs by Abraham Maslow (1908-1970), the lowest needs are the primary, physical ones. Social needs are higher whereas moral needs are at the top. The need for food and safety displaces here the need for reading. It was expressed by Lejb Goldin in the text written in August 1941 in the Warsaw Ghetto, entitled Kronika jednej doby, found in the Ringelblum Archive (cf. Żebrowski, http://www.jhi.pl/psj/Goldin_Lejb_(Lejbl) ${ }^{12}$.

I am hungry. I want to eat, eat, eat! [...] Seven hours - you say, you fool, that it is only. So that's the question how to bear these seven hours, oh well, nearest two hours? You read, you have no head for it. But you pull the book out from under the pillow. German. Arthur Schnitzler. Such and such publisher, year of edition, printing house. "Ewa looked at the mirror". You turn over the first page and suddenly you realise that you understood nothing but the first sentence. "Ewa looked at the mirror"13.

You finish the second page already and you still understand nothing. Yesterday the soup was watery and again cold. When you added salt, it was impossible to mix. Yesterday also Frydman died. From hunger ${ }^{14}$

This panoramic work, devoted mainly to the fight against poverty and exclusion, can be interpreted in a post-extermination manner.

Let's go back then to Les Miserables which also enable afterimage reading. Sara Zyskind, who was an inmate at Auschwitz since August 1944, then an inhabitant

12 A writer of the Yiddish language and translator, born in 1906 in Warsaw, died in 1942 in Treblinka, collaborator of the Ringelblum Archive. Rafał Żebrowski established: "In literature you can often find the statement that he died of hunger in the ghetto, although probably he was taken to Treblin$\mathrm{ka}$ in summer 1942. The reason for this misunderstanding is his most known work, published in the Yiddish language in Cwiszn tebn un tojt (Między życiem a śmiercią, 1955; translation into Polish by Jan Leński, „Więź”, 1977 and in: R. Sakowska, Dwa etapy..., 1986), which is an autobiographical record of life in the ghetto, also known as Dwadzieścia cztery godziny głodu": ("W literaturze spotyka się często twierdzenie, że zmarł z głodu w getcie, choć prawdopodobnie został wywieziony do Treblinki latem 1942. Przyczyną tego nieporozumienia jest najbardziej znany jego utwór, opublikowany w języku jidisz w Cwiszn łebn un tojt [Między życiem a śmiercia, 1955; przekład na j. pol. Jana Leńskiego, „Więź”, 1977 i w: R. Sakowska, Dwa etapy..., 1986], będący autobiograficznym zapisem przeżyć gettowych, znany też pt. Dwadzieścia cztery godziny głodu".

13 "Jestem głodny. Jeść, jeść, jeść! [...] Siedem godzin - powiadasz, głupcze jeden, że to zaledwie. No właśnie, jak wytrzymać te siedem godzin, ba, najbliższe dwie godziny? Czytasz, nic ci nie wchodzi do głowy. Mimo to wyciągasz książkę spod poduszki. Niemiecka. Arthur Schnitzler. Wydawca taki a taki, rok wydania, drukarnia. Ewa patrzyła w lustro. Odwracasz pierwszą stronę i nagle uświadamiasz sobie, że nic więcej nie zrozumiałeś poza pierwszym zdaniem. Ewa patrzyła w lustro" (August 1941, the Warsaw Ghetto. The essay [by Lejb Goldin] entitled Kronika jednej doby, in: Sakowska 84-85).

14 „Kończysz już drugą stronę i dalej nic nie rozumiesz. Wczoraj była rzadka zupa i jeszcze do tego wystygła. Dosypałeś soli, której nie dało się rozmieszać. Wczorajszego też dnia umarł Frydman. Z głodu" (Goldin, in: Sakowska 85). 
of a kibbutz in Israel, in the volume Skradzione lata recollected her father reading the very five-volume novel by Hugo, which was written for two decades, and published in 1862:

My father, a keen reader, told me also entire fragments of Les Miserables or The Count of Monte Cristo. From time to time he also read books by writers creating in Yiddish, such as Sholem Asch or Sholem Aleichem ${ }^{15}$.

The novel by Hugo appears in her other recollection:

In panic I looked around the vicinity, my mind worked at its highest speed. I was near the church surrounded by a high wall, the top of which was covered with shattered glass. An image of Jean Valjean of Les Miserables came to my memory. I started to climb the wall, but my feet slid on brown bricks, with hardly any props. Finally I managed somehow to get on the top. I didn't even feel that sharp slivers of glass cut my hands. [...] I sat several hours in the hiding place [...], madly frightened that Germans would track me down ${ }^{16}$.

Particularly striking is the beginning of the second volume when we recall the images of children from the Warsaw Ghetto:

Paris has a child, and the forest has a bird; the bird is called the sparrow; the child is called the gamin. Couple these two ideas which contain, the one all the furnace, the other all the dawn; strike these two sparks together, Paris, childhood; there leaps out from them a little being (Hugo, s.d, 977).

goes to the play every evening, if he sees good. He has no shirt on his body, no shoes on his feet, no roof over his head; he is like the flies of heaven, who have none of these things. He is from seven to thirteen years of age, he lives in bands, roams the streets, lodges in the open air, wears an old pair of trousers of his father's, which descend below his heels, an old hat of some other father, which descends below his ears, a single suspender of yellow listing; he runs, lies in wait, rummages about, wastes time, blackens pipes, swears like a convict, haunts the wine-shop, knows thieves, calls gay women

15 „Ojciec, zapamiętały czytelnik, przekazywał mi też całe fragmenty Nędzników czy Hrabiego Monte Christo. Od czasu do czasu czytywał też książki pisarzy tworzących w języku jidysz, takich jak Szalom Asz czy Szolem Alejchem" (Zyskind 10).

16 „Spanikowana obiegłam wzrokiem okolicę, mój umysł pracował na najwyższych obrotach. Znajdowałam się nieopodal kościoła, okolonego wysokim murem, którego szczyt wysypano tłuczonym szkłem. Przez pamięć przebiegł mi obraz Jeana Valjeana z Nędzników. Zaczęłam wspinać się na mur, ale stopy osuwały mi się po brązowych cegłach, nie dając prawie oparcia. Wreszcie jakoś zdołałam dostać się na górę. Nawet nie poczułam, że ostre okruchy szkła kaleczą mi ręce. [...] W kryjówce [...] siedziałam kilka godzin, przerażona do szaleństwa, że Niemcy mnie wytropią" (Zyskind 10). 
thou, talks slang, sings obscene songs, and has no evil in his heart. This is because he has in his heart a pearl, innocence; and pearls are not to be dissolved in mud (Hugo, s.d., 977-978).

Janusz Korczak must have remembered this passage when he himself observed children and sparrows (Korczak 163). In Pamiętnik $i$ inne pisma $z$ getta he noted: "Sometimes a book or a visit of a colleague [...]"17. In another place: "We deceive ourselves: I haven't got any paper. I will read Jacques the Fatalist by Diderot"18. Among books which he was choosing was the novel Les Miserables. In the note Rzecz o chtopcu imieniem Zuzel the Old Doctor wrote, using the associations with Gavroche, a brave little hero of the streets of Paris by Hugo, who, actually, can be associated also with Lusiek Błones, the youngest, thirteen-year-old insurgent in the Warsaw Ghetto:

1. - I met him when I was a patient of the hospital in Dworska Street two years ago, then I saw him in Leszno Street after I moved. - A ten-year-old boy, the favourite of the whole staff and patients - merry, enterprising, energetic - healthy and strong - a type of Gavroche of Misérables ${ }^{19}$.

2. - I met him in the street, already as a resident of the boarding school in Dzielna Street: trudging at a slow pace toward Smocza Street. I recognised him today, an old man, with difficulty ${ }^{20}$.

It is significant that the outstanding Polish literary scholar, Michał Głowiński, residing as a child, among others, in the Warsaw Ghetto, read the books by the French novelist after he turned 15, and he also associated the world in these novels with that world known from the ghetto. Głowiński in the Black Seasons (Czarne sezony) recollected:

I came across one of the novels by Victor Hugo - and I was fascinated by it. I read voraciously his other works; they suited me maybe because the accounts of various atrocities played such an important role in them ${ }^{21}$.

17 „Czasem książka albo odwiedziny kolegi [...]" (Korczak 48).

18 "Oszukujemy się: nie mam papieru. Będę czytać Diderota Kubuś fatalista” (Korczak 83)

19 „1. - Spotkałem się z nim jako pacjent szpitala na Dworskiej przez dwoma laty, potem po przeprowadzce widziałem go na Lesznie. - Chłopiec dziesięcioletni, faworyt całego personelu i chorych wesoły, przedsiębiorczy, energiczny - zdrowy i silny - typ Gavroche’a z Misérables" (Korczak 167).

20 „2. - Spotkałem go na ulicy, już jako wychowańca internatu na Dzielnej: ospałym krokiem wlókł się w stronę Smoczej. Z trudem poznałem tego dziś już starca" (Korczak 167).

21 „Wpadła mi w ręce któraś z powieści Victora Hugo - i mnie zafascynowała. Rzuciłem się na inne jego utwory; odpowiadały mi one może dlatego, że tak dużą rolę grają w nich relacje o różnych okrucieństwach". 
One of Victor Hugo's novels fell into my hands - and it fascinated me. I threw myself at his other works; they may have suited me because the descriptions of various atrocities play there such an important role. In some aspects they overlapped with what became a part of my experience ${ }^{22}$.

\section{The first books as the last books. Towards micro-history}

The last area of reading which interests me in this article is related to children. Eva Weaver writes about one of the heroines of fictional prose: "She browsed through consecutive books, in particular One Thousand and One Nights. She read them all" 23 . In a non-fictional account Władysław Dov Kornblum lists: "Little Lord Fauntleroy, The Prince and the Pauper, Sława, Uncle Tom's Cabin] Mały Lord, Ksiązę i żebrak, Sława, Chata wuja Toma" (Kornblum 2002: 27). In almost all personal documents there are passages devoted to books. Justyna Kowalska-Leder, while examining the diary by Renia Knoll, noticed:

Perhaps the lifelessness of the ghetto, its isolation from nature, explains to some extent the reading taste of Renia, for example her admiration for Pojednanie by Helena Zakrzewska [...] or Scandinavian literature. [...] Below the note expressing her enthusiasm for Richard the Lionheart by Walter Scott, Renia places the fragment of The Merchant of Venice:

Hath

not a Jew eyes? hath not a Jew hands, organs,

dimensions, senses, affections, passions?

(http://shakespeare.mit.edu/merchant/full.html) $)^{24}$

In her first autobiographical novel of 1987, written in Tel Aviv and entitled Jesień młodości, Miriam Akavia, born in Cracow, recollects Władek:

22 „Wpadła mi w ręce któraś z powieści Victora Hugo - i mnie zafascynowała. Rzuciłem się na inne jego utwory; odpowiadały mi one może dlatego, że tak dużą rolę grają w nich relacje o różnych okrucieństwach. Pod pewnymi względami nakładały się na to, co stało się moim doświadczeniem".

23 "Wertowała kolejne książki, w szczególności Baśnie tysiąca i jednej nocy. Czytała je wszystkie” (Weaver 62).

24 „Być może martwota getta, jego odcięcie od przyrody, tłumaczy nieco czytelnicze gusta Reni, na przykład jej zachwyt nad Pojednaniem Heleny Zakrzewskiej [...] czy literaturą skandynawską. [...] Pod notatką wyrażającą zachwyt Ryszardem Lwie Serce Waltera Scotta Renia umieszcza fragment Kupca weneckiego:

Alboż to Żyd nie ma oczu, nie ma rąk, organów, zmysłów, namiętności?” (Kowalska-Leder 108) 
[...] he was my close friend. We spent the most beautiful moments of youth together.

[...] We talked a lot, shared impressions of the read books written by Karl May and Jack London ${ }^{25}$.

Another girl from the ghetto, the niece of the Nobel Peace Prize laureate Joseph Rotblat, Halina Pokorna, also spent time reading. During archaeological excavations of the Pokorny family life, the topic of reading returns continually. When Halina's uncle, Ewa Rotblat's brother, Joseph Rotblat, born in Warsaw, lived in Liverpool and Los Alamos during the war, his brother-in-law, Mieczysław Pokorny, carried out diary notes from the ghetto and Otwock, where the family was hiding since the spring of 1943 having escaped from Warsaw - in the same house with the Nazi criminal Willy Laue ${ }^{26}$. In the meantime his little daughter, Halina Pokorna (later Parker, married name Sand) explored the further vicinity in her imagination. She spent the majority of her war childhood immersed in the consecutive pages,. Reading books - by Verne, Żuławski - helped Joseph Rotblat see the opportunities of science in childhood. It helped his niece close her eyes against the conditions of the war. When she was ten, she explored the classics of Polish literature and the translations from English.

One of her friends from the ghetto was Ryszard Cybulski from the neighbourhood. They read the same books, played Indians - like Miriam Akavia and Władek. 'I will never forget him. No one else will remember him', she said. Children with whom she was at school in the Warsaw ghetto in Nowolipki street had never grown up and got old.

During the countless hours spent by candlelight behind the wardrobe, she read The Wonderful Adventures of Nils by Selma Lagerlöf, The Secret Garden by Frances Hodgson Burnett, adventures of Anne Shirley of Green Gables (the books by Lucy Maud Montgomery were translated by Janina Mortkowiczowa), and about the boys from the novel by Ferenc Molnár, the book also translated by Mortkowiczowa. Janusz Korczak wrote: "[...] each person wards off boredom and longing in different ways" 27 . For Halina Pokorna reading was the method of warding off longing and boredom, paraphrased by the doctor as the hunger of the soul (Pl: głód ducha). "A soul longs in a cramped cage of a body. [...] If you do not believe in a soul, you have to acknowledge then that your body will be like green grass, a small cloud. For you are water and dust after all" 28 - the Old Doctor cited the words of this cemetery admonition. During the war no one dared to look into the future so far, so as to

25 „„...] był moim serdecznym przyjacielem. Razem przeżyliśmy najpiękniejsze chwile młodości. [...] Dużo rozmawialiśmy, wymienialiśmy wrażenia z przeczytanych książek Karola Maya i Jacka Londona" (Akavia 44).

26 I wish to thank Mieczysław Pokorny's (Martin Parker's) family for making the material available: I thank Peter Sand, Katherine Sand and Harriet Sand.

27 „[...] każdy broni się inaczej przed nudą i tęsknotą" (Korczak 30).

28 „Duch tęskni w ciasnej klatce ciała. [...] Jeśli nie wierzysz w duszę, musisz przecież uznać, że ciało twoje żyć będzie jako trawa zielona, jako obłok. Jesteś przecież wodą i prochem" (Korczak 30). 
dream that Halina would graduate from Somerville College in Oxford (philosophy, political and economic sciences) in 1957, and later English literature in 1981 at the University College London, and during her long career as an editor and publisher she would work on the Macmillan Dictionary of Art and the Dictionary of National Biography.

As her daughter Katherine Sand said in the interview, she particularly liked the novel Bibi by Karin Michaëlis, a Danish writer and social activist born in 1872, deceased in 1950 in Copenhagen, who during the first world war was involved in charity in Austria and after the war she joined in the activities related to making people aware of the growing threat of fascism. In March 1927 she visited Poland where her novels were published (among others, under Polish titles: Sznur peret, Panna Jonna and Serce mojej matki). In the years 1929-1938 she created a series of six novels about Bibi growing up. Also Bibi can be interpreted through the prism of the afterimage and probably little Halina also used this key of interpretation. In the letter to her father, Bibi from the novel creates an image that perfectly overlaps with the view of the house in Otwock where Halina together with her mother lived under assumed identities after escaping from the ghetto a month before the uprising in April 1943. The novel about Bibi tells the story about a girl living with a false name:

Every [creature] starts from the point of being born, even a small sparrow. To be born this is a very important thing, but to be named is even a bigger issue ${ }^{29}$

One blonde girl wearing long plaits does not like her name, Urszula, so she and her friend exchange names.

'Bibi is suitable for fair hair; we can exchange names if you want!'

'We will exchange names! - I do not know if my parents allow me to do so... You remember how my mum was angry with me when we exchanged dresses, because your dress was stained and was too tight under the arms for me.'

'Oh, it doesn't matter! My name has no stains. You want to swap?'

'Well... OK... but all my books are signed Bibi.'

'So let's exchange the books, too!'30

29 „Każdy zaczyna od tego, że się rodzi, nawet mały wróbelek. Urodzić się - to rzecz bardzo ważna, lecz jeszcze o wiele ważniejszą sprawą jest otrzymać imię" (Michaelis 30).

30 " - Bibi nadaje się do jasnych włosów; chcesz, zamienimy się imionami!

- Zamienimy się imionami! - Nie wiem, czy mi rodzice pozwolą...

Pamiętasz, jak się mama na mnie gniewała, gdyśmy się zamieniły sukienkami, bo Twoja suknia była splamiona i uciskała mnie pod pachami.

- Eh, co tam! Moje imię nie ma plam. Chcesz się zamienić?

- No... tak... ale wszystkie moje książki są podpisane Bibi.

- No więc zamieńmy się i książkami!" (Michaelis 32). 
The child's experience of reading during the war in the ghetto becomes important in the memoirs by Alona Frankel, also containing afterimage signals, for instance, when she mentions a popular story for children:

In a clock similar to this one a small goat kid of my fairy tale was hiding, my favourite fairy tale - this one about a small goat kid hidden in a clock, while a bad wolf was devouring his six brothers. I was this little goat kid ${ }^{31}$.

You can read this passage on the level of an even bigger metaphor, and in each of six little goats see one of the millions of Jews murdered during the Holocaust.

On one of the first pages of the memories the author addresses books and their heroes as the residents of her parallel world which allowed her to survive as she declares:

Cosette from Les Miserables, a magnanimous little lord, Tom Sawyer, Anna Louise and Anton, Emil and all detectives, Mowgli and Bagheera - the black panther, Jean-Christophe, David Copperfield, d'Artagnan, David of the Thibault family, and Sergei of The Storm by Ilya Ehrenburg, Konstantin Levin and Pierre Bezukhov, blue-eyed prince Myshkin, small Ernő Nemecsek of The Paul Street Boys, and brave Oliver Twist.

Thank you, my heroes. [...] Thank you for the worlds which you created for me, which were opened before me $[\ldots]^{32}$.

\section{The End Part}

Maria Orwid, a doctor-psychiatrist and the pioneer of family therapy in Poland, born in an assimilated Jewish family and in 1942 settled in the Przemyśl ghetto, in the book Survive... And what next? inquired about her fatherss motivation to read during the war:

I noticed there was some kind of crowd. I came closer and saw that some German soldiers were kicking with their boots a man lying on the ground and screaming terribly.

31 „W zegarze podobnym do tego ukrywało się małe koźlątko z mojej bajki, mojej ukochanej - tej o małym koźlątku, które siedziało ukryte w zegarze, podczas gdy zły wilk pożerał jego sześciu braci. Ja byłam tym koźlątkiem" (Frankel 56).

32 „Cosette z Nędzników, wielkoduszny mały lord, Tomek Sawyer, Kruszynka i Antoś, Emil i wszyscy detektywi, Mowgli i Bagheera - Czarna Pantera, Jan Krzysztof, Dawid Copperfield, d'Artagnan, Dawid z rodziny Thibault i Sergiej z Burzy Ilii Erenburga, Konstanty Lewin i Pierre Biezuchow, błękitnooki książę Myszkin, mały Ernest Nemeczek z Chłopców z Placu Broni i dzielny Oliver Twist. Dziękuję wam, moi bohaterowie. [...] Dziękuję wam za światy, które stworzyliście dla mnie, które się przede mną otwierały [...]" (Frankel 12). 
The crowd watched. After a moment, I realized that the man they were kicking was my daddy. [...] Finally, the soldiers left him alone and went away. He stood up with difficulty. [...] Since that event, he didn't leave his house all year long. He was sitting at the table between two windows all day and was reading Shakespeare's collected works [...]. Today I know that while he was reading Shakespeare, he was saving his dignity ${ }^{33}$.

In the "closed district" the role of literature was to move people beyond the wall, to bring spiritual relief. Many people which remain in detention tell about its power. Prisoners in the Italian top-security prison spent time reading. In the film Caesar Must Die by the Taviani brothers, dedicated to the play by Shakespeare staged by prisoners, one of them states: „I had been in prison before I discovered Shakespeare". Children from the orphanage of doctor Janusz Korczak also recognised this power of literature. They were imprisoned yet blameless, looking for similar power in literature when they were staging the play by Tagore. The rebels from the besieged eastern Aleppo were reading till the evacuation in December 2016, where in October 2016 the library on wheels was established. In November 2016 in the entries on Twitter, conducted from eastern Aleppo by a seven-year old girl, Bana Alabed, we could read her declaring that she was reading to forget about the war.

Reading is one of the aspects of the micro-history of the ghettos. The question "what did people read in the ghetto" can be included in this practice which consists in describing small territorial and time spaces. This question highlights the interest in problems of everyday life, beliefs, customs of the members of local communities, which is often ignored by traditional historiography dealing with mainly great processes and outstanding units. There are doubts, however, whether the studies on ordinary life in extraordinary times can be considered micro-historical, and in extreme situation - studies on the Holocaust. While reading The Forty Days of Musa Dagh, Les Misérables and Bibi I was mainly interested in the context which emphasised their instructive character and provided sense to an unreal reality. The reader's situation of storylines in such time allows them to have a new impact.

"(O)ur tongue becomes for them / the language of an ancient planet" (translation: Louis Iribarne) - Czesław Miłosz, cited at the beginning of this paper, wrote about the impossibility of conveying the terror of the Holocaust, its extremity and therefore of the impossibility of expressing the experiences of the victims in any language. The literature of the ghettos sometimes becomes a prism and allows you not

33 „Zauważyłam tam jakieś zbiegowisko. Podeszłam bliżej i zobaczyłam, że niemieccy żołnierze kopią buciorami leżącego na ziemi człowieka, wrzeszcząc przy tym okropnie. Przyglądał się temu tłum gapiów. Po chwili zorientowałam się, że człowiekiem, którego kopią, jest mój tatuś. [...] W końcu żołnierze zostawili go w spokoju i odeszli. Wstał z trudem. [...] Od tego wydarzenia przez cały rok nie wyszedł ani raz z domu. Całymi dniami siedział przy stoliku, pomiędzy dwoma oknami, i czytał dzieła zebrane Szekspira [...]. Dziś wiem, że czytając wtedy Szekspira, ratował swoją godność" (Orwid 46-47). 
only to cast new light on the subject of life and dying of the ghettos, but also enables to activate new ways of reading the books chosen by the residents of the ghetto. Both Musa Dagh and Les Miserables are critical novels, acting not only with a blade of a tongue, but by the very plots. Those imprisoned in the ghettos probably thought, paraphrasing Flaubert: „I am Jean Valjean”, „Musa Dagh is our Nowolipki street”.

\section{BIBLIOGRAPHY}

Akavia, Miriam. Jesień młodości. Przeł. Mosze Plessner. Kraków: Wydawnictwo Literackie, 1989.

Auron, Yair. The Banality of Indifference: Zionism and the Armenian Genocide. New Jersey: Transaction Publisher, 2009.

Auron, Yair. The Forty Days of Musa Dagh. Its Impact on Jewish Youth in Palestine and Europe. Hovannisian

Richard G., ed. Remembrance and Denial: The Case of the Armenian Genocide. Detroit, Michigan: Wayne State University Press, 1999.

Frankel, Alona. Dziewczynka. Przeł. Leszek Kwiatkowski. Warszawa: Nisza, 2007.

Głowiński, Michał. Czarne sezony. Warszawa: Open, 1998.

Grossman, Haike. The People of the Underground. Tel Awiw: Sifriyat Poalim, 1965.

Hugo, Victor. Der giber in keytn, Les Miserables: a lebns-drame in zeks bilder. Trans. Zvi Hirsh Dashevsky. Vilne: Farlag Hirsh Mats, 1925.

Hugo, Victor. Les Miserables. Trans. Isabel F. Hapgood. Planet eBook (s.d, s.l.).

Hugo, Wiktor. Nędznicy, tom 2. Warszawa: Iskry, 1986.

Kassow, Samuel D. Who will write our History? Emanuel Ringelblum, the Warsaw Ghetto, and the Oyneg Shabes Archive. Bloomington: Indiana University Press, 2007.

Korczak, Janusz. Pamiętnik i inne pisma $z$ getta. Przypisy Marta Ciesielska, posłowie Jacek Leociak. Warszawa: W. A. B., 2012.

Kornblum, Władysław Dov. Ostatnia latorośl. Wspomnienia małego chłopca z getta warszawskiego. Warszawa: Ypsylon, 2002.

Kornblum, Władek. „Byłem zaścielony w łóżku”. Grynberg, Mikołaj. Ocaleni z XX wieku. Po nas nikt nie opowie, najwyżej ktoś przeczyta. Warszawa: Świat Książki, 2012.

Kowalska-Leder, Justyna. Doświadczenie Zagłady z perspektywy dziecka w polskiej literaturze dokumentu osobistego. Wrocław: Monografie FNP, 2009.

Kronenberger, Louis, "Franz Werfel's Heroic Novel: A Dramatic Narrative That Has Stirring Emotional Force". New York Times Book Review, 2 grudnia 1934.

Miłosz, Czesław. Poezje wybrane. Selected Poems. Przeł. różni, posłowie Autora. Kraków: Wydawnictwo Literackie, 1996.

Orwid, Maria. Przeżyć... I co dalej? Rozmawiają Katarzyna Zimmerer i Krzysztof Szwajca. Kraków: Wydawnictwo Literackie, 2006.

Ringelblum, Emanuel. Kronika getta warszawskiego, wrzesień 1939 - styczeń 1943. Wstęp i red. Artur Eisenbach. Przeł. z jidisz Adam Rutkowski. Warszawa: Czytelnik, 1988. 
Roszak, Joanna. „Musa Dah i bliżej. Zaczynając od powieści Franza Werfla”. Slavia Occidentalis 2 (2015). S. 83-93.

Wajsbort, Inka. Together and Yet Alone in the Face of the Terror. Tel Awiw: Moreshet, 1992.

Serkowska, Maria. Wstęp do: Wiktor Hugo, Gavroche. Fragment powieści Nędznicy. Przeł. Ludmiła Dunikowska. Warszawa: Instytut Wydawniczy Nasza Księgarnia, 1960.

Werfel, Franz. Czterdzieści dni Musa Dah. Przeł. Jacek Frühling, wiersze przeł. Ryszard Stiller. Poznań: Zysk i Ska, 2013.

Weaver, Eva. Lalki z getta. Przeł. Magda Witkowska. Warszawa: Prószyński i S-ka, 2013.

Wisse, Ruth R. The Modern Jewish Canon: A Journey Through Language and Culture. Chicago: University of Chicago Press, 2003.

Zyskind, Sara. Skradzione lata. Przeł. Anna Wiśniewska-Walczyk. Warszawa: Czytelnik, 1991.

Żabińska, Antonina. Ludzie i zwierzęta. Kraków: Wydawnictwo Literackie, 2010.

\section{Internet sources:}

Campo di Fiori by Czeslaw Milosz from The Collected Poems: 1931-1987. Copyright ( 1988 by Czeslaw Milosz Royalties, translation: Louis Iribarne. Used by permission of HarperCollins Publishers. Source: The Collected Poems: 1931-1987 (The Ecco Press, 1988), Web. 9.3.2017 <https:/ / www.poetryfoundation.org/poems-and-poets/poems/detail/49751>

Web. 9.3.2017<http://shakespeare.mit.edu/merchant/full.html> 
